\title{
1. Several central debates in development macroeconomics
}

To give an overview of several debates related to development from a macroeconomic perspective, this chapter briefly emphasizes them to provide the basis for the subsequent analysis. After starting with concentrated data on global poverty, the chapter presents the central growth theories as well as the core development debates of the past thirty years dubbed as the "Washington Consensus," and then goes on to take a look at fiscal policy, international trade and financial flows, industrial policy and institutions. Depending on economic paradigms, these topics are considered differently. Moreover, not all of them are covered by the subsequent analysis of this book, but it will become clear what role - be it more or less prominent - they play in a successful macroeconomic development strategy. Hence, while this overview aims to emphasize certain important issues, it also introduces others in order to present dominant thinking in development economics and, throughout the book, to show its gaps and shortcomings.

\subsection{POVERTY: FACTS AND FIGURES}

Poverty is hard to grasp precisely in numbers. In international development debates, income per capita dominates as the main indicator to define poverty. For instance, the Millennium Development Goals set the target to halve the number of people living on less than US\$1.25 a day between 1990 and 2015 (United Nations, 2015). This benchmark has been adjusted to US $\$ 1.90$ per day, the amount below which about 10 percent of the world population currently live on according to the World Bank (2018a). As a similar indicator, Figure 1.1 compares gross domestic product (GDP) per capita across different world regions. Income in advanced countries is a multiple of what it is in the poorest countries, that is, in Sub-Saharan Africa or in the group of the least developed countries according to the United Nations (UN) classification. The value of Western Europe is much higher than appears in the figure because its average is reduced by lower incomes in Eastern Europe and Central Asia. 


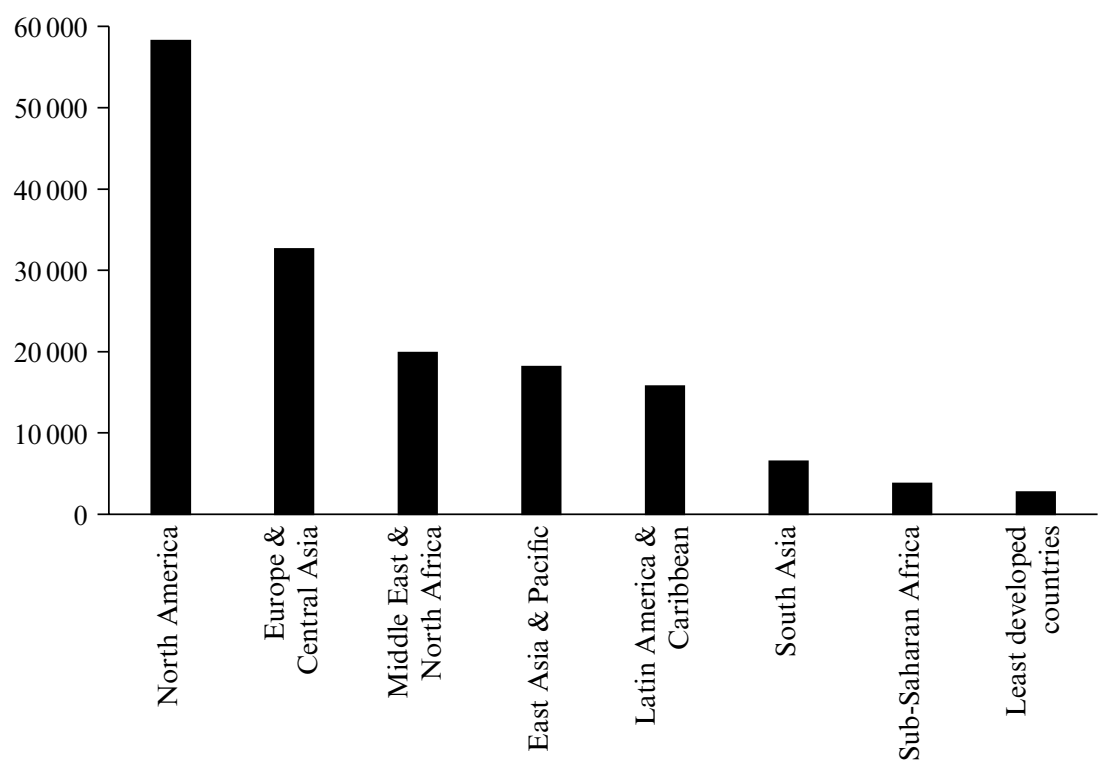

Source: World Bank (2019b).

Figure 1.1 Average GDP per capita 2017 (current international dollars)

The world is far from any automatic convergence of income levels. Economic growth in East Asia and the Pacific was the highest in the world throughout the past 60 decades in almost every year, as Figure 1.2 depicts. Growth was first driven by Japan, then by the so-called "Tiger" states of South Korea, Singapore and Taiwan, to be followed by the constant and high-speed growth rates of mainly China up to the present. In this sense it is valid to suggest a convergence process, as emerging countries in East Asia are catching up to North America and Western Europe, which are richer but featured lower growth rates during the same time period. A less impressive but partially analogous argument can be made for South Asia, as India has grown quite fast since 2000. However, catch-up is much slower given the still very low per capita income of the country. Latin America and the Middle East and North Africa regions generally grew at slightly lower rates than industrial countries. Sub-Saharan Africa featured hardly any long-term growth even though it is the poorest world region. Growth also tended to be lower for the least developed countries. Since there was strong population growth, per capita income has actually fallen there.

However, poverty estimates using income as an indicator face serious 


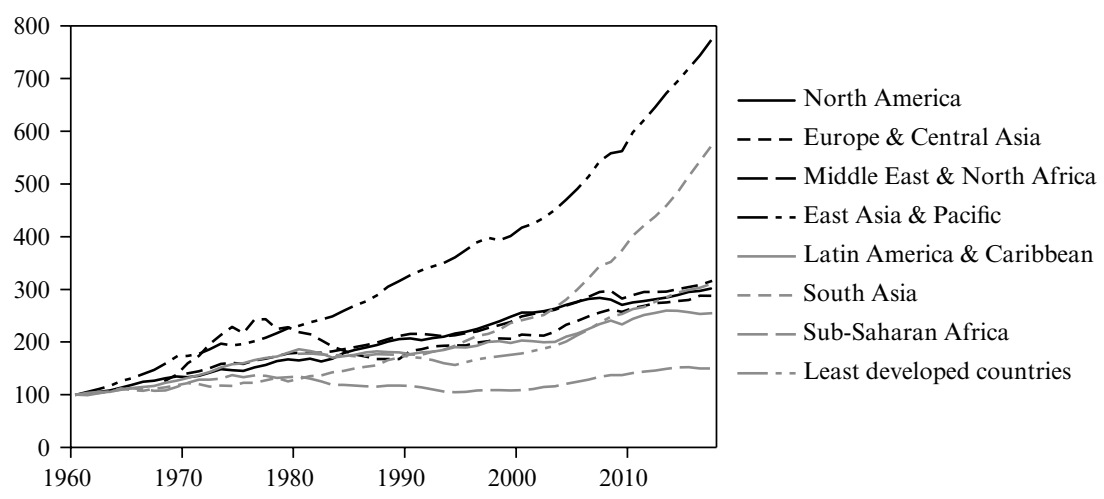

Source: World Bank (2019a), author's calculations.

Figure 1.2 Economic output 1960-2017 (1960=100)

measurement problems, such as the choice of an international standard basket of consumer goods or the construction of price indices and international purchasing power parities (see for example Edward \& Sumner, 2018, pp. 488-490). Events such as the surge in food prices from 2005 to 2008 are hardly reflected in these data (Woodward, 2015, pp.50-51). Moreover, these benchmarks measure poverty in absolute terms, thus ignoring the relative measure, that is, inequality in income and wealth. Yet, there is strong empirical evidence that inequality produces outcomes which make a society poorer with regard to people's well-being. For example, more unequal societies reveal more violence, status consumption, more abuse of drugs, more stress and therefore more health problems than others (Wilkinson \& Pickett, 2017). In this sense, inequality produces a kind of poverty which is invisible when referring only to income per capita. Even though this book touches upon the issue of income distribution in general, it does not particularly focus on it. Nonetheless, income per capita should be supplemented by further data to provide a more accurate picture of poverty.

The United Nations' Human Development Index adds life expectancy at birth and school education to income per capita (UNDP, 2019). Despite still being far from perfect, such indicators broaden the view. Indeed, as is argued by Dasgupta (1993, p. 115), life expectancy at birth is the best indicator to measure well-being. Figure 1.3 depicts the development of life expectancy in different world regions. We observe a slight convergence, as the poorer countries have been able to catch up whereas life expectancy in richer world regions grew slower. Yet, the difference between Sub-Saharan 


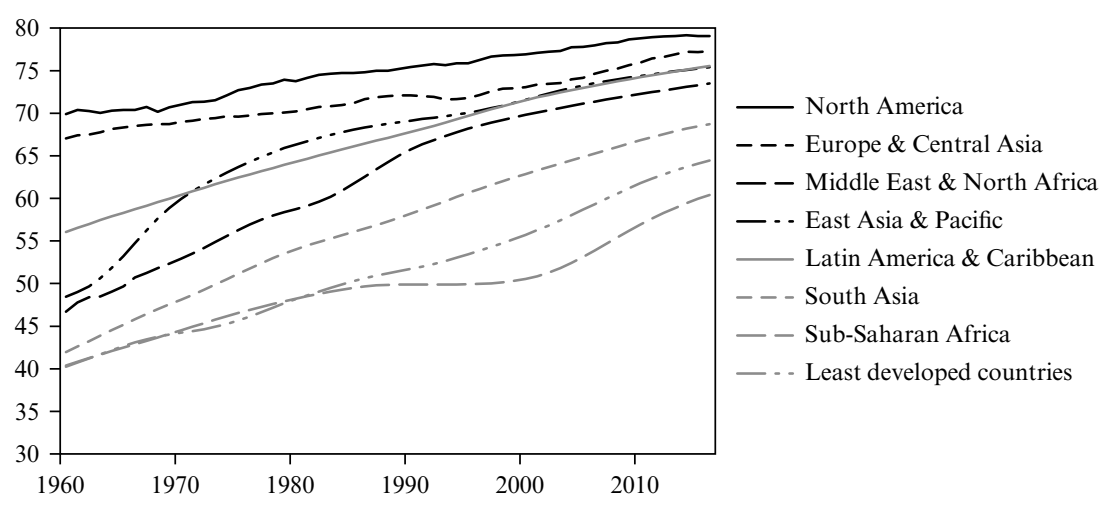

Source: World Bank (2019c).

Figure 1.3 Life expectancy at birth in number of years, 1960-2016

Africa and North America is still 19 years. The dip in the curve of SubSaharan Africa can be explained by the AIDS crisis in Southern Africa which reduced life expectancy drastically before medical treatment was improved (see World Health Organization, 2018).

Living conditions may also be described by economic life in a society and the share of the population working in the informal sector. The informal sector does not provide a regular income and is marked by low revenues, uncertainty, stress and precarious working conditions. It is a robust economic indicator because it does not depend on calculations of price indices and difficult international definitions. Moreover, it may also give hints about the productive structure of an economy. The proportion of workers in vulnerable employment, including own-account workers, is depicted in Figure 1.4. While the respective shares in advanced economies have remained constantly low, they have fallen strongly, by 27 percentage points, in East Asia and the Pacific during the last almost 30 years. However, in all other emerging and developing world regions, proportions have remained rather stable. In Latin America, South Asia and SubSaharan Africa, the decrease in vulnerable employment was only between 4 and 8 percentage points. In South Asia and Sub-Saharan Africa, about three-quarters of workers are engaged in vulnerable employment. This means that the large majority of workers depend on precarious day-to-day activities.

Needless to say, there is an extensive debate on whether the fight against poverty is successful or not. The World Bank takes the benchmark of per capita income of US\$1.90 as its bottom line and states that there has been 


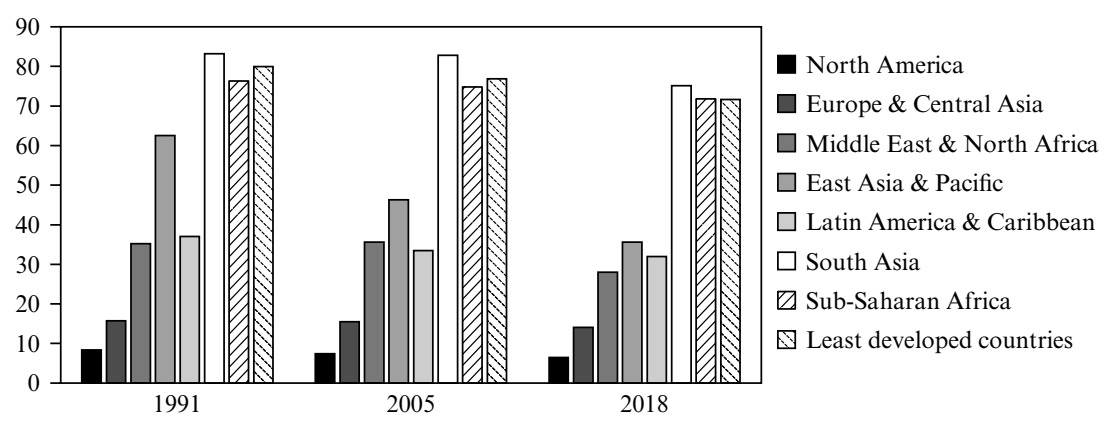

Note: The values are the unweighted average of male and female vulnerable employment.

Source: World Bank (2019e).

Figure 1.4 Share of workers in vulnerable employment, 1991-2018 (\%)

a continuous decline in poverty, but admits that the speed of reduction is too low to meet the targets of the United Nations (World Bank, 2018a). The respective old and new benchmarks of US\$1.25 and US\$1.90 are argued to be equal and a mere adjustment due to changes in purchasing power parities.

However, Lahoti and Reddy (2015) point to numerous methodological problems of such a single benchmark and even to its adjustment; they argue that the old and the new benchmarks therefore cannot be compared, which makes measuring the evolution of global poverty difficult. Moreover, the authors show that to cover just the most necessary food needs, at least US\$5 a day are necessary (ibid., pp. 12-13). According to this cost-of-food benchmark, more than 80 percent in Sub-Saharan Africa and South Asia are poor. Additionally, this percentage of the poor population only decreases slowly, while the absolute number of poor people hardly declines at all and is clearly higher than in 1990 (ibid.). In a similar vein, the most recent report of the UN Food and Agriculture Organization (FAO, 2019, pp.8-9) shows that both prevalence and number of undernourished people have been rising again since 2015.

Hickel (2017, pp.48-49) gives an example of how wrong estimates give a biased view: in India the World Bank claimed that according to the international poverty line the proportion of poor people was on a steady decline; while, in fact, the proportion of people living on less than 2100 calories a day had increased by a third between 1984 and 2011. Likewise, World Bank data state a continuous decrease of population shares living in slums at least since 1990 (World Bank, 2019d). However, a different perspective points to the fact that we have seen decades of growing 
informal settlements all over the southern world. Since the middle of the past century, the average growth rate of urban population has been higher than the growth rate of the total world population, while the slum population again has grown faster than cities in total, as argued by Davis (2006, pp. 17-19). Often, official numbers on slums are criticized by local experts for being too low (ibid., pp. 23, 26).

Another measurement problem consists in the fact that not all goods are produced under market conditions. In that case, they are not priced and therefore are not included as part of GDP. In countries where markets expand to former non-market areas, official GDP estimates increase while real wealth ceteris paribus does not. Countries are probably rather heterogeneous in this regard, such that GDP per capita measures may be biased.

Edward (2006) criticizes the official World Bank poverty benchmark by developing an alternative approach. He suggests an ethical poverty line by relating income per capita to life expectancy at birth. There is a range of per capita income where life expectancy increases considerably with every additional dollar of income. At a certain life expectancy, the slope decreases strongly, so that growing income only has a modest impact on life expectancy. This empirical observation represents a kind of a benchmark. Ethically, it can be justified that wealth distribution should be such that human years of life are maximized. Hence, people who do not reach the life expectancy benchmark because their income is too low, are considered as poor. The population above the benchmark is rich, because it has more income than necessary to achieve the benchmark and its abundant wealth does not raise life expectancy substantially further. Taking the ethical poverty line, which integrates the issue of inequality, the size of the global poor population is about three times what the World Bank estimates (ibid., p. 390).

Global poverty trends as estimated by the multilateral organizations provide an ambiguous picture, whereas alternative calculations criticize them for still being too positive. On the one hand, general health conditions seem to have improved thanks to medical progress in the long term, as can be seen from increased life expectancy. With regard to economic data, however, we observe strong differences across world regions. Most poverty reduction, in percentage as well as in absolute numbers, took place in East Asia and notably in China, where the planning state plays a much more active role in the economy than almost elsewhere in the world. The share of Chinese in the world lowest decile of income declined from 58 percent to 11 percent between 1981 and 2010 (Woodward, 2015, p. 53). This is also reflected in growth rates of that region. Growth has also been high in South Asia, but progress in poverty reduction is much less as can, for example, be seen from the proportion of vulnerable employment. Latin America and the Caribbean are somewhere in the middle of these develop- 
ments, while Sub-Saharan Africa faces the lowest growth rates, lowest life expectancy and the largest informal sectors. Finally, the perspectives to end poverty are not promising: Woodward (2015, p. 58) estimates that if the progress of the past continues, poverty as measured by the US\$5-a-day line will be eliminated in about 200 years.

This book does not analyze the roots of poverty or the advantages and disadvantages between the continents such as the amount of natural resources available for development. Nor does it argue that, for instance, certain cultures and traditions are better able to steer poverty reduction than others. Instead, it suggests that different economic development strategies produce different outcomes. The poverty data above confirm this. In particular, this book argues that any successful development path requires consistent macroeconomic governance. The theoretical analysis may reduce poverty to a one-dimensional issue, which is exactly what has been criticized here. Indeed, the model, which serves as a supportive instrument for the analysis, mainly focuses on economic growth. However, it also includes wage development and "formal" employment. Therefore, it can provide useful indications for economic policy programs. Nevertheless, it should be kept in mind that the theoretical simplifications in this book in fact represent a complex phenomenon, which is poverty and miserable living conditions in all its various aspects.

\subsection{THEORIES OF GROWTH}

When talking about developing countries, defining the term "development" is not easily accomplished. Different sciences have a different approach to it. Yet, their common bottom line is the reduction of poverty arising from material shortage, which causes physical and mental suffering. Even though development includes a large variety of different aspects, it has the removal of the material constraint at its core. Development problems are therefore, directly or indirectly, essentially economic in their nature. This applies to microeconomic issues such as rural development or education. At the macroeconomic level, those questions translate into the performance of aggregate economic activity and, hence, economic growth. While growth is not a guarantee to eliminate poverty in today's developing countries, it is the crucial precondition. Development strategies cannot be successful if they do not steer economic growth. In Bresser-Pereira's (2016, p. 341) words, “economic development is the main element of progress or human development, which also involves the increase in security, the increase of individual liberties, the reduction of inequalities, and the protection of the environment."

This chapter therefore gives a short overview of growth theories and 
relates them to the context of developing countries. Starting with the classics, Smith (1776/1976) introduced the notion of increasing returns to scale, which he explained by the division of labor, as the source of growth. By contrast, Ricardo (1821/2001, pp.40-42, 71, 58) predicted economic stagnation due to land as the limiting resource in the production process, as well as rising wages. By extending production, less-fertile land is cultivated, thus signifying decreasing returns.

Indeed, whether increasing production inputs gives way to increasing or decreasing returns decides the potential of economic growth. As a simple matter of fact, 200 years of continuous long-term economic growth show that increasing returns exist. However, this observation taken alone does not yet tell us anything about the factors driving returns to increase. In Smithian terms, division of labor may allow for increasing returns, thus entailing economic growth (see for instance Borland \& Yang, 1992). But it remains unexplained under what conditions division of labor takes place effectively, as recognized by Young (1928). There are different ways to deal with this gap.

The neoclassical model of growth, as developed by Solow (1956), starts with a standard aggregate production function whose inputs are capital and labor. Supply of labor is given by exogenous population growth. Likewise, capital accumulation is determined by an exogenous saving rate as a share of output. This model contains the assumption that all savings are automatically turned into investment. The production function is assumed to exhibit constant returns to scale, while the marginal returns to each production factor are decreasing (ibid., pp.67, 70). Maximizing the production function yields an optimal capital-labor ratio. As in any neoclassical model, returns-to-production factors adjust in a way to ensure full employment of labor and capital. This implies that when labor supply grows, growing output gives rise to increasing savings and hence a growing capital stock. There is a steady convergence to the equilibrium where the optimal capital-labor ratio under given factor prices prevails. The growth rate at this steady state is called the natural growth rate. By several extensions, Solow (1956, pp. 70-73) shows that there may be more than one equilibrium and that convergence may be quite long-term. But in essence, an equilibrium capital-labor ratio implies that growth of total output is determined by population growth and the saving rate.

There may also be technological progress taking place at a certain rate in each period (Solow, 1956, pp.85-86). It has two effects on growth dynamics: on the one hand, technological progress endows both production factors with higher productivity; output is higher, with inputs being the same. On the other hand, given the saving rate and labor supply, capital accumulation increases. 
After all, in the neoclassical growth model it is the saving rate, population growth and technological progress that determine economic performance (Thirlwall, 2002, p.22): a higher saving rate yields a higher level of output per capita because of a higher capital-labor ratio. However, it cannot influence the rate of economic growth since a higher capital-output ratio is compensated by a lower marginal productivity of capital. Population growth has a negative impact on output per capita due the lower capitallabor ratio. However, since the latter raises returns to capital, population growth triggers higher economic growth. Technological progress finally raises both output per capita and the rate of growth of total output.

The neoclassical model makes a prediction which is particularly important for developing countries: if tastes and technology are equal across countries, there is convergence in incomes per capita (ibid., 2013, p. 26). Poorer countries usually have a lower capital-labor ratio, thus implying a higher marginal productivity of capital. This allows them to grow faster and hence to approach the income levels of industrialized countries. This explanation is to be distinguished from those catch-up effects where it is suggested that poorer countries can adopt technologies of advanced economies (see for instance Abramovitz, 1990, p.2). While the former describes a move on the curve of the production function, the latter means a shift of the curve itself.

Even though the Solow model is able to assign a role to important parameters such as savings, investment, technological progress and population growth, it exhibits quite fundamental shortcomings. First, there is no empirical evidence of long-term convergence in economies' per capita incomes, at least not for capitalist economies (see for instance Baumol, 1986; Thirlwall, 2013, pp.29-31). Be it the difference in the returns to capital, or catch-up via adoption of modern technologies, there seems to be no channel that automatically leads to convergence. Second, the neoclassical model is theoretically quite weak. It describes variables but does not give an explanation of the factors driving them. Neither is it clear what determines an economy's saving rate and hence (according to the model) capital accumulation, nor is there any suggestion about where technological progress comes from. Exogeneity of those parameters circumvents the answer to important questions. This gap remains when the model is used for empirical exercises in growth accounting. By decomposing the aggregate production function, the respective contributions of capital accumulation and technical progress to economic growth per capita can be assessed (see for instance Solow, 1957). An explanation of what causes those factors to make a contribution to growth and how they are linked with other variables is missing.

Facing this criticism, neoclassical economics moved on to the so-called 
"new" or "endogenous" growth theory in the 1980s. Investment is likely not only to raise the capital stock but also to increase productivity via the introduction of new technology. Hence, returns to capital are not necessarily decreasing. In Lucas (1988), productivity increases through human capital accumulation and learning by doing. Romer's $(1986,1990)$ model is based on increasing returns to capital due to externalities arising from research expenditures. Other factors affecting the productivity of capital may be trade, macroeconomic performance and the political environment (Thirlwall, 2002, p.31). Neoclassical economists reconcile this new development by testing whether there is convergence in per capita incomes after controlling for the additional effects, which may entail increasing returns to capital. Evidence of convergence can be found (see for example Barro, 1991). However, after ruling out factors accounting for divergence in incomes, it is no surprise that convergence is revealed. Moreover, the result of convergence is not helpful if the main factors driving growth are those that raise the productivity of capital; that is, a factor that does not contribute to convergence.

New growth theory is thus not genuinely new, as argued by Thirlwall (2002, pp. 32-33). First, the observation of diverging incomes per capita across countries during the second half of the twentieth century is just too obvious to be discovered only by new growth theory. Indeed, structuralism as a distinct theory of economic development has pointed to widening income disparities between advanced and developing economies, or the center and the periphery, respectively. For instance, Prebisch's (1950, pp. 8-15) classical developmentalism emphasizes a model where the center of the world economy produces industrial goods, while the periphery provides primary goods. Since long-run productivity growth largely goes along with industrialization, the productivity gap between the center and the periphery widens. At the same time, Prebisch (1950, p.9) observed terms of trade evolving in favor of industrial goods from the 1870s until the 1940s. Hence, productivity gains in the center were not shared with the periphery. Quite the opposite: the periphery received fewer industrial goods in exchange against primary goods and thus was deprived of resources. Insufficient returns from foreign trade prevented the import of capital goods to foster industrialization in the periphery. Other analyses of causes of growth divergence, likewise ahead of the new growth theory, were made by Myrdal (1957), Hirschman (1958) and Emmanuel's (1972) Marxian analysis of unequal exchange.

New growth theory was not first, either, in discovering that capital may feature increasing returns. Instead of assuming technological progress to be exogenous, intuition tells us that there is causality in both directions between investment and technological progress: productivity growth 
triggers investment, while investment strengthens productivity via the establishment of new production plants and equipment. Indeed, this is what Kaldor (1957, p. 604) suggested by proposing a direct relationship between investment and output growth where the channel is technological progress rather than a move on the curve of the production function. Thus, foundations of heterodox growth theories may tell us more about growth dynamics.

Yet, there are further shortcomings even in new growth theory, which also apply to Kaldor (1957). The neoclassical model is a supply-side framework where there is no role for demand (Thirlwall, 2002, p.24). This has far-reaching implications. First, the model assumes that output is determined by the existing capital stock, labor input and technology represented by the production function. Hence, the capital stock is always fully employed, signifying full capacity utilization. The same applies to employment. The total labor force enters the production function at a wage level consistent with labor market clearing, so that there is no unemployment. Second, neoclassical theory assumes that agents save a share of their income, which is then automatically invested. According to the model, savings determine investment. The share of income not consumed today provides the foundation for output growth tomorrow. With output growth and technological change being exogenously given, economic growth becomes quite predictable. New growth theory adds uncertainty by making technological progress endogenous. However, the supply-side determination of the model and the causality from savings to investment remain.

Heterodox growth theories, borrowing from both post-Keynesian and classical approaches, have more insights to share in this regard as well. The idea that savings cause investment can no longer be sustained once the monetary system is introduced to the analysis, as will be explained in the following chapter. Investment does not rely on preliminary savings, thus allowing for altered growth dynamics as revealed by Robinson (1969/2013). Moreover, in reality, production capacity is far from being permanently fully utilized. Whereas classical models converge to a socalled normal rate of capacity utilization in the long term while it varies in the short run, Kaleckian and neo-Kaleckian approaches tend to reject a natural convergence towards full utilization even in the long run (see for instance Blecker \& Setterfield, 2019, pp. 281-282).

To give a sketch of the real dynamics of the macroeconomy, let us take investment and employment as being determined by producers' expectations. Investment grows if it is expected to be profitable. Employment is increased when sales in the close future are expected to increase. If these conditions are fulfilled, growing expenditures imply higher aggregate 
demand and thus higher capacity utilization. Investment then may well introduce new technologies and thereby raise productivity and economic growth in the long term.

Yet, if the conditions are not satisfied, demand is in a slump. Economic activity stagnates and there is a lack of investment to enlarge long-run production capacity. Technological progress thus is also essentially influenced by demand conditions. As León-Ledesma and Thirlwall (2002) show, the so-called natural rate of economic growth, often referred to by heterodox growth theory and defined by Harrod (1939) as the rate at which capacity utilization and employment are constant, is influenced by the actual growth rate. This means that strong demand, by driving current economic activities, also shifts production capacity and thus the economy's growth potential. It does so via the strengthening of investment and technological progress. Supply-side factors remain important, but they are neither exogenously given nor do they exclusively determine economic activity. Insufficient demand is an important barrier which prevents productivity growth and keeps developing countries stuck in poverty, as will be argued in the remainder of this book.

Once the supply-side determination is given up and economic growth is considered as demand-driven, it becomes obvious that there is neither a guarantee nor a tendency towards a stable or even a positive growth path. Given that, depending on the strand of research within heterodox theories, profitability matters for investment and the wage level affects the level of demand, income distribution obviously becomes an important determinant of economic performance. Whereas the relevance of distribution is a common feature of most post-Keynesian models, including particularly Kaleckian and neo-Keynesian models, as well as classical approaches, it is not included in neoclassical foundations (see Blecker \& Setterfield, 2019). Yet, the wage level, and hence the wage share in total income is a key variable affecting profitability and demand. Within heterodox economics, opinions differ on what pattern wages should follow. While post-Keynesians suggest that wages should grow in line with productivity to maintain demand and keep the wage share stable (see for example Cynamon \& Fazzari, 2016; Stockhammer, 2015), classical economists support wage increases only to the extent that they do not jeopardize profitability, which may be better complied with if wages grow slower than productivity (see Shaikh, 2016, pp. 760-761; Shaikh, 2018, pp. 151-152).

Finally, mainstream growth models are constructed as a closed economy. But once it is recognized that countries are embedded in the world and have trade and financial relationships, the issue of growth becomes more complicated. External liabilities and exchange rate fluctuations set limits to a country's growth potential and require a more sophisticated development 
strategy to create a space where productivity can be strengthened while employment is ensured. Heterodox theories, building on Kaldor (1970a), emphasize the importance of export markets as the essential drivers of growth. On the other hand, economic growth raises the demand for imports, which gives rise to the so-called external constraint that requires a balanced current account (Thirlwall, 1979). Those limits to growth that any small developing country faces are a central issue of this book.

The new developmentalism approach, making use of development economics and post-Keynesian macroeconomics, is an important more recent contribution in this regard, as it incorporates heterodox growth theory as well as the implications of the open economy (Bresser-Pereira, 2016, 2020). It distinguishes itself from classical developmentalism by its embrace of a more macroeconomic theory and its focus on middle-income countries (Bresser-Pereira, 2020, pp.629-630). But new developmentalism also provides insights for developing countries, notably regarding its concern with the exchange rate and its implications for growth.

\subsection{THE WASHINGTON CONSENSUS}

To find one of the very key milestones, if not the central one, that has influenced development economics to this day, we have to go back to 1989. John Williamson presented a paper with a reform agenda he considered to be consensus among the "people in Washington" (Williamson, 2004-05, p. 195). Notably, Washington in this regard also includes the international financial institutions based there. The reform agenda included ten policy instruments and was targeted to Latin America. It has come to be known as the Washington Consensus. The ten points were the following (ibid., p. 196):

1. Fiscal discipline to avoid inflation.

2. Redirecting public expenditure priorities in favor of neglected fields with high economic returns such as health, education and infrastructure.

3. Tax reform combining a broad tax base with moderate marginal tax rates.

4. Financial liberalization with the ultimate objective of marketdetermined interest rates.

5. A competitive exchange rate to promote exports of non-traditional sectors.

6. Trade liberalization where quantitative restrictions are first replaced by tariffs, which are reduced step by step down to a uniform range of 10 to 20 percent. 
7. Liberalization of foreign direct investment (FDI).

8. Privatization of state enterprises.

9. Deregulation to ease entry and exit barriers for firms.

10. Provision of property rights, particularly to the informal sector.

If the Washington Consensus did not itself lay the base for a new trend in development economics, it at least described the dominating paradigm in a concise form, and came to be the object of an intensive debate in the following decades. The debate concerns development economics and development policies, but also globalization in general, and neoliberalism as an economic and political dogma. The general intention of the program was the achievement of higher living standards and more productive economies in the Global South through enhanced competition. As will be understood in the following analysis, the Washington Consensus is based on the view of a supply-determined economy in line with the principles of the neoclassical growth model. According to the basic assumptions, efficient markets entail optimal resource allocation. Intervention of the public sector, barriers to trade and financial market regulation would only induce distortions and inefficiencies. Therefore, budget deficits should be small, and the role of the state should be reduced while trade, interest rates and financial flows should be liberalized.

The Washington Consensus was criticized immediately after its formulation. International financial institutions are accused of applying the Consensus's program to developing countries without taking care of the countries' specific needs (see for instance Stiglitz \& Schoenfelder, 2003). Moreover, the program is considered as being harmful to developing countries, because markets are liberalized while the idea of development is based on wrong ideas of markets and institutions (see Chang \& Grabel, 2004-05).

Facing the criticism, the original agenda was extended. The intention was not to reverse, but "to complete, correct and complement the reforms" (Kuczynski \& Williamson, 2003, p. 18). The update, called After the Washington Consensus, contains a new agenda consisting of four additional elements (ibid., pp.320-321): fiscal policies should be complemented with a Keynesian element of anticyclical spending. Together with inflation targeting, flexible exchange rates and strict budget discipline of subnational governments, economies can be stabilized in crises. In addition, the revised agenda proposes second-generation institutional reforms including the political system, the civil service, the judiciary and the financial sector. Moreover, they involve a national innovation system, the modernization of property rights and bankruptcy laws, and the strengthening of prudential supervision (Marangos, 2012, p. 591). 
As Marangos (2012, p.591) argues, these propositions are consistent with the role of the state in mainstream economics, which is "creating and maintaining effective institutions, providing public goods; internalizing externalities; correcting income distribution; providing decent infrastructure, a stable and predictable macroeconomic, legal, and political environment, and a strong human resource base." Finally, the Consensus is to be amended by a social agenda aiming at a partial income redistribution. The fiscal system should become more progressive, while tax revenues should be spent for the empowerment of poor people by providing them with resources such as education, land and credit (Kuczynski \& Williamson, 2003, p. 321). Even though the Washington Consensus still considers growth as always being in favor of the poor, the poor need resources to start with, thus requiring initial support (Marangos, 2012, p. 591).

The Washington Consensus, including its amendment, has been the focal point of development macroeconomics to date, despite - or perhaps precisely because of - continuous criticism arguing for its failure (see Rochon, 2006a, p.107). Its agenda was targeted to Latin American countries, but the recipes have been implemented in both developing and advanced economies. The Consensus's components are thus still central issues in current debates.

\subsection{FISCAL POLICY AND THE ROLE OF THE STATE}

Discipline in government budgets is the requirement listed first in the Washington Consensus. The justification given by mainstream economics is twofold. First, fiscal deficits are considered as the source of balanceof-payments crises, inflation and even hyperinflation (Williamson, 2003, p. 1476; Woo, 2006, p. 1). According to this view, government deficits, if used for the provision of consumption goods, induce savings to fall short of expenditures (Gemmell, 2004, p. 154). Therefore, growing demand pressure meets restricted supply-side conditions, thus giving rise to inflation. Inflation deteriorates the building of expectations and increases uncertainty, which harms investment and capital accumulation. To the extent that budget deficits are created to pay for imports, supply shortages in the domestic economy may be prevented. But this comes at the cost of current account deficits, currency depreciation and balance-of-payments crises.

The second reason for fiscal discipline is given by the market-driven paradigm. The Washington Consensus aims at strengthening the private sector and competition. A stronger role of the market in economic decision relies even more on price stability to prevent price distortions (Kregel, 
2008, p. 548). The public sector thus should not be allowed to influence market prices by inflationary budget deficits.

The Consensus criticizes the use of fiscal deficits as a macroeconomic policy tool, which is argued to involve instability. Therefore, it requires primary surpluses, even in recessionary periods (Câmara Neto \& Vernengo, 2004-05, p. 334). Primary surpluses exclude the payment of interest. Such tight restrictions strongly reduce the role of the so-called developmental state (see for instance Chibber, 2014; Williams, 2014). The requirement of constant surpluses is a drag on public investment. Even though mainstream theory, including the Washington Consensus, suggests efficiency of unregulated markets, economic fluctuations are an indisputable fact in capitalist economies. Public investment not only increases the productive potential of an economy in the long term, but also creates demand by making expenditures for investment goods. This contributes to employment and output, and hence enables the government to stabilize output (Câmara Neto \& Vernengo, 2004-05, p. 335). This potential powerful role of the state is constrained by the requirement of fiscal discipline. This is the point where heterodox economics criticizes the mainstream stance on fiscal policy as expressed by the Consensus.

Not all fiscal deficits are alike. Keynesian analysis recommends the separation of the budget into a current budget and a capital budget (Câmara Neto \& Vernengo, 2004-05, p. 335). The former covers consumption spending, while the latter defines investment expenditures. The difference is obvious. In contrast to consumption, investment often generates future returns. And investment materializes in a real asset, which is part of the government's wealth. Hence, while public debt arising from consumption is not sustainable in the long run, the capital budget may well include a certain level of debt. First, there is a possibility to repay debt out of investment returns. Second, a comprehensive consideration of public debt considers not only financial debt but also the real assets backing that debt. Net debt is thus lower or can even be negative, thereby denoting net public wealth (see Llorca, 2017, pp.177-178). Additionally, public debt should also be considered in relation to a country's output in order to judge its affordability. Higher output increases the resource potential out of which returns and tax revenue can be generated to repay debt in the future.

Câmara Neto and Vernengo (2004-05, pp.339-340) point to another dilemma of fiscal discipline that applies to development economies being open towards the rest of the world. To keep the exchange rate stable and prevent capital flows out of the country, interest rates have to be at a sufficiently high level. High interest rates ceteris paribus means high interest payments. Therefore, the primary surplus needs to be considerably large for the deficit after interest not to be too large. Even though there is even- 
tually a deficit, it still does not contribute to domestic demand when interest has to be paid on foreign debt. In an open economy with high interest rates, the squeeze on public investment is thus particularly pronounced.

The consensus view of fiscal policy is based on the observation of fiscal deficits going along with inflation and balance-of-payments problems. It is implicitly assumed that budget deficits cause macroeconomic instability, so that fiscal discipline is the cure to make the economy more stable. However, there is a causality in the opposite direction, which is at least as important. High economic growth implies high returns of firms and households who are taxed by the government. A sound tax base means higher tax revenue. Moreover, public enterprises enjoy higher profits. Fiscal surpluses are the consequence. On the other hand, bad economic performance shrinks the tax base and results in higher budget deficits. From this, it follows that eliminating fiscal deficits to prevent macroeconomic instability is not necessarily the best option. Cutting budgets means shrinking demand and hence further contributes to recession. Instead, considering fiscal policy as responsible for maintaining a high level of demand requires deficits in times of deteriorating economic performance (Arestis \& Sawyer, 2010b, p. 334).

Besides the question of whether or not fiscal deficits are allowed for developing countries, another issue is the role that can be attributed to the public sector in general. The same budget surplus or deficit can go along with either a high or low share of the public sector in economic activity. Laissez-faire economics assigns a minimized role to the government in order to prevent price distortions and inefficiencies in self-regulating markets. Alternative theories rely more on the idea of a developmental state, which fosters development via public investment and also directs private funds to politically defined priority sectors (see for instance Bagchi, 2004; Chibber, 2014). In this regard, public investment targets more than output stabilization. Its core is the long-run development of productivity and output growth in poor countries.

Justification for state-driven investment can be found, on the one hand, in transformative economics and theories on economic planning where public intervention is required to speed up economic development and to fully utilize the existing productive resources (Kalecki, 1942/1986, p. 20; Kalecki,1966/1972, p. 117). On the other hand, Keynes (1936/1997, p. 378), who doubted that the private sector alone is able to ensure permanent full employment, suggested the "socialization of investment" where the government cooperates with the private sector and takes over the investment necessary to eliminate unemployment.

A look at data shows the importance of the public sector in economies at different stages of development. Figure 1.5 plots public investment in 


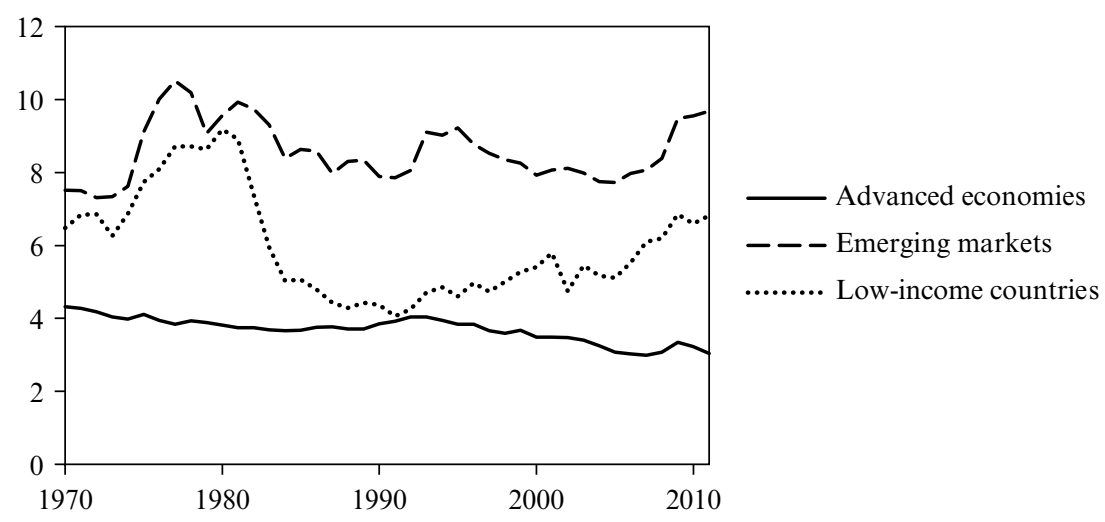

Note: For the exact classification of advanced economies, emerging markets and lowincome countries, refer to IMF (2014, pp. 161-167).

Source: International Monetary Fund (2014).

Figure 1.5 Real public investment in percentage of GDP, 1970-2011

advanced economies, emerging markets and low-income countries from 1970 to 2011. Public investment as a percentage of GDP reveals a longterm decline in advanced economies. Emerging economies, containing among others the BRICS countries (Brazil, Russia, India, China, South Africa) face public investment double the size of their GDP, where no clear trend is visible in the long run. Low-income countries are between the two former country groups. After a drop in the share of public investment due to the debt crisis at the beginning of the 1980s it has increased again since, but has not reached the former high level. Even though not all investment is equally efficient and macroeconomically important, it is striking that the country group with highest growth rates - that is, the emerging economies - also features the highest relative public investment.

At the same time, Figure 1.6 shows that public investment does not necessarily come with higher public debt. The figure reveals gross and net debt as a ratio to GDP of selected countries of the respective group of advanced, emerging and developing countries. Overall, it can be seen that both gross and net debt ratios tend to be higher in advanced economies than in emerging and developing countries. The reasons for this difference are not elaborated in detail in this book. But a sketch of it can be given by the macroeconomic principles and the basic model developed in the following chapter. Namely, lower growth rates caused by slowly progressing productivity, as observed in industrial countries, require a higher demand 


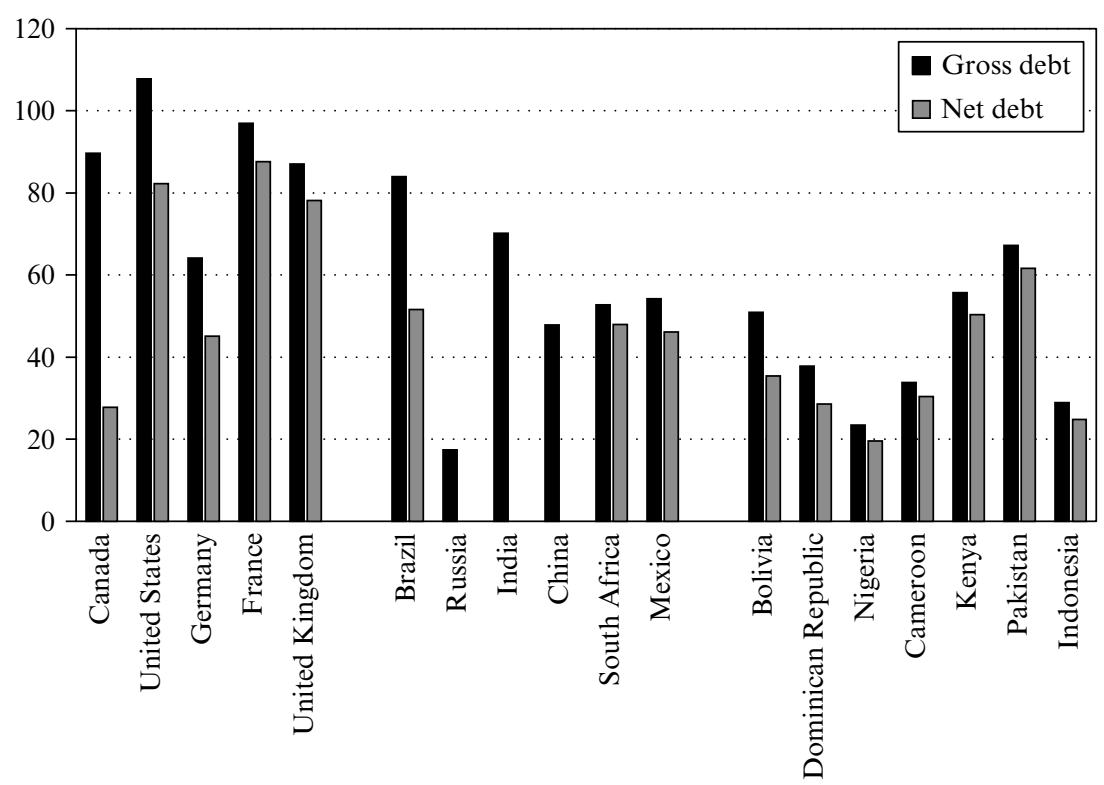

Source: International Monetary Fund (2018).

Figure 1.6 Gross debt and net debt as a percentage of GDP in selected countries, 2016/2017

stimulus to maintain full employment. The government is an important source of such a stimulus, be it via welfare programs or tax cuts.

Advanced economies can usually sustain higher debt levels without interest rates going up or the exchange rate depreciating. Investors tend to have more confidence in industrial countries' institutional strength and capacity to manage public debt than in the case of emerging and developing economies.

In relation to fiscal discipline, mainstream economics such as the Washington Consensus also emphasizes the role of the public sector by recommending the privatization of state enterprises. The sale of public assets is, indeed, one of the central pillars of the Consensus. It is justified, on the one hand, by the more prominent role that should be given to the private sector, for "true" prices and market-driven factor allocation to work out in favor of efficiency and, eventually, growth and prosperity. On the other hand, it is also argued that privatization makes public firms as entities in themselves more efficient and productive (Brune et al., 2004, p. 196). However, even though empirical evidence on the economic benefits of privatization of public enterprises is mixed, privatization policy 
has been pursued with great intensity, as thousands of entities have been privatized since the 1980s (ibid., pp. 195-196). Moreover, selling public assets is argued to contribute to good fiscal performance. Even though this provides only a one-time return, privatized companies can be taxed and thereby contribute to state revenues. Data on Latin America show that tax revenues as a percentage of GDP have increased steadily since the 1990s (Economic Commission for Latin America and the Caribbean, 2018, p. 43). This may reflect the indirect impact of privatization.

Criticism of privatization from academics and civil society points to the importance of public provision of basic services for the poor population in developing countries. When the Washington Consensus lost dominance during the "noughties," privatization also featured a marked slowdown (see Chong \& López-de-Silanes, 2005, p.1). Besides ethical and social considerations, the role of the public sector is of cardinal importance to economic performance, as it can support employment in the short term and productivity growth in the long run. This aspect is neglected by neoliberal economic agendas recommending privatization of public assets.

The analysis of this book emphasizes the issue of fiscal policy in detail and assesses the potential role that the public sector can play in a developing country. Therefore, the general objections of neoclassical theory against active government intervention concerning market distortions, financing constraints and the crowding-out of the private sector have to be emphasized. Thorough macroeconomic monetary analysis reveals their weakness. Our alternative view shows that an economy is far from automatically establishing optimal factor allocation, but may rather face demand and profitability constraints, and thus cannot generate full employment and long-term development of a country. Public intervention can thus be useful in influencing effective demand, employment, long-term capital accumulation, growth and poverty reduction. Beyond past and current trends in fiscal policy debates, this analysis shows the potential impact that the public sector can unfold to foster development.

\subsection{TRADE LIBERALIZATION}

Opening countries to international trade flows has been one of the core issues of the Washington Consensus where the only potential disagreement is the speed with which trade should be liberalized (Williamson, 2003, p. 1476). To date, it is on the agenda of almost all mainstream development economists, and particularly of the World Trade Organization (WTO). Neoclassical economic theory finds a number of benefits arising from free trade, that is, the elimination of tariffs and other non-tariff barriers. ${ }^{1}$ First, 
opening domestic goods markets to the rest of the world increases the degree of competition. It is not only the most efficient firm in the domestic economy which dominates the market, but the most advanced producer globally. Inefficient firms are thus closed, while efficient ones can expand (IMF et al., 2017, p. 19). The more economies of scale there are, the more they can be exploited by trade (see Helpman \& Krugman, 1989). Trade helps to transfer technology and knowledge across countries, particularly to developing countries. These spillovers increase the productive capacity of the world economy and also of each country. Producers can import inputs to production at a lower price instead of purchasing them in the domestic economy. Likewise, consumers get access to cheaper goods of a higher variety (IMF et al., 2017, p. 19).

Overall, the argument in favor of free trade states that trade liberalization removes barriers and distortions and thus helps the economy to approach the optimal equilibrium point. The intuition is provided by David Ricardo's (1821/2001, pp.85-103) theory of comparative advantage. It recommends that countries should specialize in the production of goods they are best at. This would maximize the productivity and wealth of the economies. Taking Ricardo's model of two countries and two goods, even if one country can produce both goods at lower cost than the other country, both countries should specialize in the respective good which they can produce at relatively lower cost. Free trade is required so that countries can exchange their goods against those they do not produce. This is the precondition for specialization.

Critics of free trade point to potential costs that may arise from trade liberalization. Some sectors may benefit from cheaper input material, while others lose market shares in the domestic economy due to competing imports. Some sectors might therefore experience a loss in employment (OECD, 2005). Proponents of free trade argue that these are short-run adjustment costs that are more than compensated by gains in other sectors. In the same vein, it is claimed that potential benefits from protectionism are only short-term (Nash \& Mitchell, 2005, p. 37).

However, there is criticism of the free-trade paradigm that goes beyond transitional imperfections. As will be argued throughout this book, critical arguments essentially point to the fact that neoclassical theory is focused merely on exchange, while ignoring the production process. Yet, goods have to be produced before they can be exchanged. Domestic production needs to be sufficient for exports to pay for imports. Technological progress and productivity growth are the crucial factors driving production in the long run. However, the theory of comparative advantage does not say anything about this (Skarstein, 2007, p. 352). Today, free trade policies based on the theory of comparative advantage in fact suggest 
that advanced economies specialize in industrial goods, while developing countries focus on agricultural goods and primary goods in general. This corresponds well with Prebisch's (1950, pp. 8-15) center-periphery model. The problem is that industrial goods and agricultural goods involve different demand patterns in the course of economic development. Income elasticity of demand is higher for the former than for the latter, as stated by Engel's law. This means that there are inherent limits to the demand for agricultural goods.

Moreover, Kaldor's growth laws (see Thirlwall, 1983, pp.345-346), based on empirical evidence, show that economic growth goes along with growing manufacturing output, while the latter is also correlated with growth in labor productivity in and outside of the manufacturing sector. This includes Verdoorn's law, which states that there is a significant correlation between output growth and productivity development (Arestis \& McCombie, 2006, p. 3). This means that as long as production in developing countries is limited to agricultural goods, productivity growth is low (Skarstein, 2007, p. 353). As a consequence, advanced economies grow faster than poor countries. Even worse, industrialization also strengthens productivity in the agricultural sector such that, even here, advanced economies can be more productive than developing economies. Comparative advantage thus turns into an absolute advantage for industrial countries (ibid., p.361), implying an absolute disadvantage for poor countries. Free trade and specialization in the primary goods sector according to the theory of comparative advantage is thus considered a "dead end for underdeveloped economies" (ibid., p. 347).

According to many heterodox economists, tariffs and export subsidies should therefore be applied such that they maximize promotion of economic development (see for example Chang \& Grabel, 2004, pp.61, 66). This may amount to the violation of comparative advantage considerations in the short term by favoring productivity growth in the long run. However, protection is exactly what today's industrial countries applied in their earlier stages of development (see Wade, 2003, p. 631).

The trend to trade liberalization is evident, as Figure 1.7 shows. The examples of several advanced, emerging and developing economies reveal a cut in average tariffs on imports of manufactured goods, ores and metals since the late 1980s and early 1990s in all country groups. The higher the original tariff rates, the larger the reduction. The differences between countries have thus become smaller, whereas advanced countries already had quite low tariff rates before. Currently, tariffs in most countries are quite low, but still a bit higher in poorer countries. Tariffs also depend on a country's specialization, which defines the sectors where protection is needed. Yet, average tariff rates of different sectors in larger 


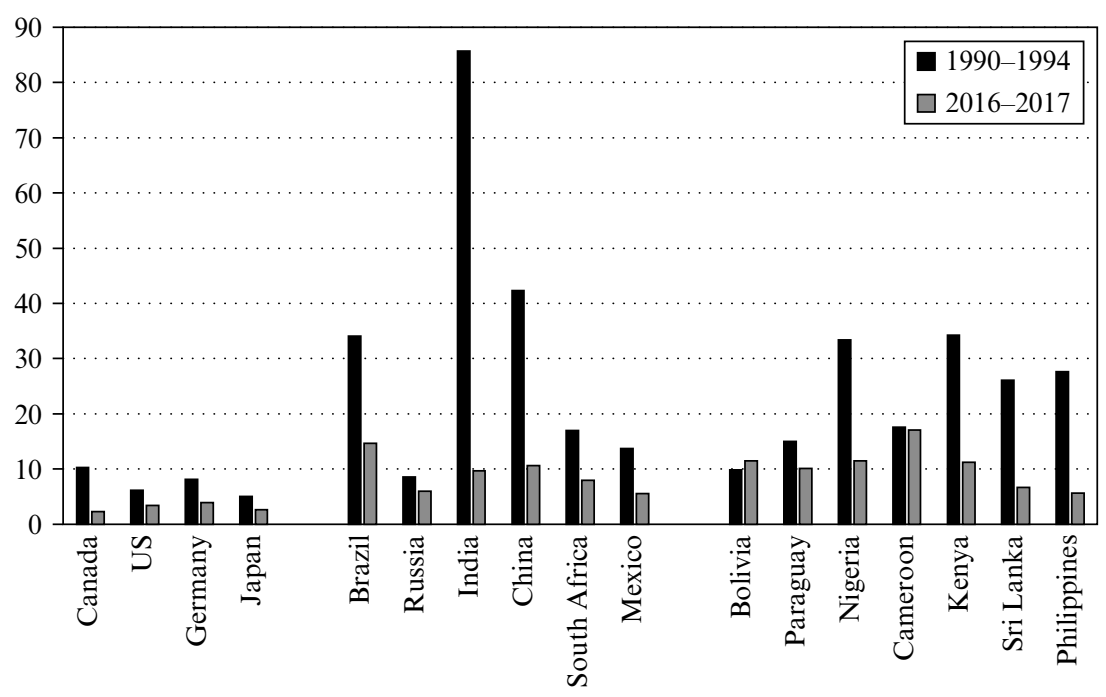

Source: UNCTAD (2018).

Figure 1.7 Average tariffs on imports of manufactured goods, ores and metals (exact year depending on data availability)

sets of countries confirm the conclusion from Figure 1.7 (see UNCTAD, 2017, p. 5).

There is a large volume of empirical literature on the effects of trade liberalization. De Loecker and Goldberg (2014) show that it improves firm performance. On the one hand, input costs decrease; while there are demand effects on the other hand, possibly coming from lower prices and economies of scale. However, it is not clear whether trade liberalization improves firm performance through higher profitability within firms, or also via the actual reallocation of physical resources. Regarding actual impacts on productivity, Ahn et al. (2016) estimate that trade liberalization in advanced European countries between 1991 and 2012 increases total factor productivity. This result is confirmed by Amiti and Konings (2007), who estimate the impact on productivity in Indonesia from 1991 until 2001, where they find that the effect of reductions of input tariffs is much stronger than that of output tariffs. A similar study for India between 1986 and 1993 also finds a positive but quite weak impact on total factor productivity (Topalova, 2004).

There is further research on additional aspects. Carrère et al. (2018) test for the impact of trade liberalization on employment and find mixed results. The change in employment depends on whether the sectors of 
comparative advantages favored by liberalization have efficient or inefficient labor markets.

The question of whether free trade merely strengthens productivity or also improves living conditions of large shares of the population is positively responded to by Fajgelbaum and Khandelwal (2016), who argue that trade favors the poor due to lower prices of many goods in their basket. With a calibrated general equilibrium model for Nigeria, Shuaibu (2017) finds a positive but quite small effect of trade liberalization on poverty reduction. Dollar and Kraay (2004) argue that developing countries which open their economies to trade grow faster than the other developing countries, while the impact on the poor is also positive. Notably, the sample of the open countries in this study also includes China and India. Regarding the quality of products, Amiti and Khandelwal (2013) provide mixed evidence, finding that the quality of goods that are close to the quality frontier improves with trade liberalization, while quality improvement for the other goods is discouraged.

However, not all of the literature presents positive results arising from free trade. Pacheco-López (2005) provides evidence of the effects of trade liberalization and particularly of the North American Free Trade Agreement (NAFTA) in Mexico by considering the time period from 1973 until 1999. Liberalization has increased the propensity of GDP to import more strongly than its propensity to export. This means that a given growth rate implies a deteriorated balance of payments. ${ }^{2}$ Consequently, the growth rate consistent with balanced trade is lower than before. The impact of NAFTA on growth is thus argued to be negative (ibid., p. 613).

A similar outcome is attained by Pacheco-López and Thirlwall (2007), testing for the impact of trade liberalization on 17 Latin American countries between 1977 and 2002. For most countries, the trade-off between growth and balanced trade has deteriorated. Some of those countries grew faster, but only at the expense of a worsened balance of payments. Siddiqui (2015) argues that developing countries had lower growth rates after the trade liberalization period starting in the 1980s than before. Dowrick and Golley (2004) compare developing and advanced economies and find that openness to trade favored economic convergence of poor and rich countries in the 1960s and 1970s, but has not done so since the 1980 s, when it was mostly to the favor of advanced economies. In an analysis of the trade liberalization reforms in Brazil in the early 1990s, Arbache et al. (2004) provide evidence of wages falling thereafter in both traded and non-traded sectors.

The utility of free trade for economic development remains inconclusive. Empirical research often provides results without establishing a comprehensive theory. This book does not have a particular focus on trade regimes, but 
embeds trade into a whole macroeconomic framework. It will come back to the issues of exchange and production: the former cannot take place without the latter. Trade thus cannot be considered in isolation. Different macroeconomic issues are important for a development strategy to be successful.

\subsection{FINANCIAL LIBERALIZATION}

What started as "interest rate liberalization" in the Washington Consensus was reformulated to "financial liberalization" to emphasize the topic in a broader way, as suggested by Williamson (2002, p. 1). The term covers the deregulation of financial flows in the domestic economy as well as internationally. Moreover, it points at more competition in the banking system. To date, the financial liberalization debate continues, particularly on aspects such as financial market development in developing countries.

The rationale for financial liberalization is given by its proponents as follows (Arestis, 2004-05, p.254): the allocation of credit should be decided by market forces for investment to be made in a growthmaximizing way. First, the market equilibrium ensures that the efficiency of capital is maximized. Second, the process of allocation of savings to their use as investment takes place in the most efficient way. Third, market forces also determine the level of savings and investment in equilibrium in an optimal way, based on preferences of agents. Financial liberalization thus influences capital both quantitatively and qualitatively. The interest rate is determined by the equilibrium of savings and investment. Hence, the market prevents the rate from being too low, such that investment projects with low profitability, and therefore low efficiency, are ruled out. The average efficiency of capital thus is increased, which raises the productivity of the economy. Higher efficiency of capital again augments real returns to capital and therefore entails higher savings and higher investment.

Financial liberalization includes two main components. On the one hand, it requires deregulation of the domestic banking system, thus reducing the influence of dominant state-owned banks and eliminating the political influence on interest rates. On the other hand, interest rates of a country can only be considered as really market-determined if they correspond to the conditions in the global financial system with respect to savings and investment. Hence, a country - that is, the space defined by its currency - should be open to foreign capital inflows and outflows. International financial liberalization allows savings and investment to equilibrate globally. If there is a relative squeeze in savings in one country, the interest rate is higher than in the rest of the world where savings are more abundant. The removal of barriers such as capital controls thus 
allows money to flow in and to align domestic interest rates with the international level. If this is not the case, according to the proponents of liberalization, investment in the domestic economy risks being inefficiently allocated because of the biased allocation signal of domestic interest rates.

Abiad et al. (2008, pp.4-6) give an overview of a set of specific liberalization measures: besides the removal of capital and interest rate controls, it concerns the abolition of credit controls such as prescriptions regarding what sectors should be provided with credit in what volume; the abandonment of entry barriers for financial institutions; withdrawal of state ownership in the banking sector; and establishing of internationally open debt and equity markets by offering tax incentives and by developing depository and settlement systems.

Since the 1970s, when several Latin American countries were first to experience financial liberalization in the developing world, the conception has faced increasing criticism and was considered as a failure in terms of enhancing economic prosperity. For this reason, the debate was widened and concerned mainly the way liberalization is achieved; that is, the optimal path to liberalized financial markets.

Liberalization proponents suggest that financial reforms should be sequenced (see Arestis, 2004-05, pp. 255-256). For instance, liberalization of the real sector should be implemented before financial markets follow, so that different sectors can react to mutual allocation signals. Likewise, opening to foreign financial markets is only to happen after liberalization of domestic financial markets (ibid.). This is a condition for a country's financial system to be able to absorb foreign capital inflows and outflows. Failure of former liberalization programs in developing countries was also attributed to the absence of banking supervision, and macroeconomic instability. In an unstable environment, efficient allocation of savings and investment is distorted. Hence, adequate banking supervision and stable macroeconomic conditions are a precondition for financial liberalization (ibid.). This includes a "liberalized and sound banking system" to deal with capital flows (Williamson, 2004-05, p. 198).

The rationale of financial liberalization is opposed by heterodox economics based on a different conception of money, interest rates and the functioning of markets. The basic assumption of financial liberalization is based on the idea of markets as being efficient and inherently stable. Yet, markets are more than the perfect equilibration of supply and demand (and from a proper macroeconomic perspective, even about something entirely different than equilibrium, as will be shown in the next chapter). First, there are obstacles such as imperfect information (see Stiglitz \& Weiss, 1981). Asymmetric information between lenders and borrowers gives rise to risk premia on interest rates and credit rationing. 
Moreover, there are nominal rigidities entailing time lags. Financial markets react more strongly to news than goods markets, but their dynamic interaction involves non-linear convergence to equilibrium, if any. Even more importantly, there is the issue of uncertainty, this quite fundamental idea developed by Keynes (1936/1997, pp.161-162). Uncertainty is absent in neoclassical economics. Where it is addressed, it is reduced to a perception of risk even though, in fact, it is something very different from the distribution of probabilities. Uncertainty, developed in more detail in this book, implies that the future is unforeseeable. Agents in the economy thus have to make assumptions, build expectations and rely on conventions (Arestis, 2004-05, p. 257).

In reality, as heterodox approaches state, the way production, investment and exchange take place is quite different from what neoclassical models suggest. Moreover, production requires money. Money is not something like savings, which have to be available for investment to take place, as mainstream economics argues. Instead, it is created out of nothing by the banking system, and needs to be associated with production in order to attain purchasing power. It will be shown that there is no need for the economy to converge to an equilibrium that guarantees stability. Regarding financial liberalization, the essential problem emanates from the fact that the banking system can create money without limits, which influences prices in financial markets and thereby can create instability. Speculative bubbles may burst and trigger financial crises.

Most developing countries do not have well-developed voluminous financial systems. Therefore, foreign capital flows usually are a higher risk to macroeconomic stability than the isolated domestic banking system. Capital flows may consist not only of long-term foreign direct investment but also of short-run portfolio flows with possibly speculative intentions. Capital account liberalization thus exposes the countries to irregular and sometimes immediately reversing capital inflows and outflows. They affect risk exposure of the domestic banking system and of the whole economy via the impact on the exchange rate. While capital inflows may create financial bubbles, sudden outflows tend to trigger banking and financial crises. In particular, this concerns the phenomenon of capital flight, as mentioned in the Introduction to this book. A country with a liberalized capital account is exposed to financial fragility. Economic policy thus has to be in line with the demands of financial markets in order to prevent capital from flowing out of the country and triggering a currency crisis. Honohan and Klingebiel (2000, pp. 27-28) provide evidence of the high economic costs of financial crises after financial liberalization reforms, of which the Asian crisis in 1997 is perhaps the best-known one. 
The final objective of financial liberalization is efficient resource allocation, which is argued to increase economic growth, welfare and the efficiency of financial systems (see for instance Fischer, 1997). However, the argument that market-driven interest rates are growth-maximizing is based on the paradigm of the interest rate being determined by the equilibrium of savings and investment. Yet, post-Keynesian monetary theory argues that the interest rate is not needed to equilibrate savings and investment; instead, the short-term interest rate level is set by monetary policy (see for example Rochon, 1999, p. 14). The lower the interest rates, the more profitable the investment. Economic activity thus can be strengthened if interest rates are kept below the level determined by neoclassical market equilibrium. Such interest rate level setting by central banks, termed "financial repression," was a common practice in developing countries in the 1950s and 1960s (Arestis, 2004-05, p. 254). Moreover, selective credit and investment allocation was applied in countries where public banks dominated, in order to concentrate resources on specific sectors in favor of long-run technological development (see for instance, Chang, 2003, p. 262; Zhu, 2007, p. 267). Such development strategies are far from liberalized financial markets, but can be effective in fostering growth.

There is considerable empirical research on whether financial liberalization achieves its objectives. Galindo et al. (2007), by investigating 12 developing and emerging countries in Latin America and Asia, find that financial liberalization improves the efficiency with which investment funds are allocated. The same outcome is presented by Hermes and Meesters (2015), conditional on the sufficient quality of bank regulation and supervision. However, such results are an expression of the exclusively profit-oriented character of private investment in contrast to public investment. The latter may target sectors with low profitability but great importance for the long-run development of an economy. Such investment does not drive efficiency in neoclassical terms, but instead drives productivity.

With respect to the impact of financial liberalization on economic growth, Townsend and Ueda (2007) find ambiguous results for Thailand from 1976 to 1996. Estimates collected in a meta-study by Bumann et al. (2013) find mostly insignificant results; whereas Bekaert et al. (2009) provide evidence of a positive impact on growth for a set of 96 countries between 1980 and 2006. Likewise, Owusu and Odhiambo (2014) provide support that financial liberalization strengthened economic growth in Nigeria in the observed period from 1969 to 2008. By contrast, another study analyses the impacts of financial liberalization on industrialization in Malawi and concludes that firm concentration increased thereafter, entry of new firms fell, while financing constraints for small and mediumsized enterprises were not removed (Kabango \& Paloni, 2011). In a review 
of studies on financial liberalization in Sub-Saharan African countries in the period from 1980 to 2004, Fowowe (2011) shows a wide range of results with regard to economic growth and concludes that the expected gains have not materialized. Additionally, there is evidence that capital account liberalization increases income inequality in an economy (Furceri \& Loungani, 2018).

The channels through which financial liberalization makes economies more prone to financial fragility and crises is examined by a voluminous literature. In two case studies on Mexico and South Korea, Kwon (2012) shows that fast-paced liberalization attracted short-term foreign capital, feeding stock markets rather than productive activity. In contrast to foreign direct investment, short-term flows triggered financial and currency crises in 1994 in Mexico, and in 1997 in South Korea. Using indices of financial instability and financial liberalization, Batuo et al. (2018) investigate 41 African countries between 1985 and 2010 and find that financial liberalization goes along with more financial instability. Yang et al. (2019) provide empirical support for the argument that financial liberalization involves surges and flights of capital, which may trigger financial crises as regards, notably, portfolio flows in emerging countries. This finding is confirmed by Arestis et al. (2006).

This book provides a detailed theoretical analysis of the fundamental mechanisms of monetary and financial systems. Based on the key principles of macroeconomics, the meaning of domestic and international financial flows is assessed. We will see that the exposure of developing countries as small open economies to the rest of the world implies numerous complex interdependencies that a development strategy should take into account. To prevent macroeconomic instability including banking and currency crises, a proper monetary analysis is required.

\subsection{INDUSTRIAL POLICY}

While liberalization of trade and financial flows is a top priority on the agenda of international financial institutions, industrial policy is largely as absent as it was in the Washington Consensus. As will be seen, mainstream economics is based on the assumptions that there is inherent convergence of the economy to equilibrium. State intervention causes deviations from equilibrium and thus creates inefficiency. Trade and financial liberalization contribute to efficient factor allocation. This is why many development agendas are limited to liberalization of markets. Yet, considering trade as an act of exchange without taking production as its base into account does not answer the question of what goods can actually be exchanged. 
Proponents of active industrial policy thus argue that a productive economic base is the foundation of any successful development.

Productivity growth can best be strengthened by promoting those sectors that have the biggest potential of technological progress. In line with Kaldor's growth laws (see Thirlwall, 1983, pp.345-346), the manufacturing sector is the main contributor to overall productivity growth. Historically, successful development stories in general went along with a process of industrialization (Szirmai, 2012). Moreover, other sectors such as various services depend on manufacturing (see for instance Guerrieri \& Meliciani, 2005). Manufacturing takes the role of a "learning centre of capitalism in technological terms" (Chang et al., 2013, p.11), because manufactured goods are inputs in many other sectors and thereby allow for productivity spillovers. Additionally, manufactured goods generally have higher tradability than services and thereby can be exported in order to finance imports (ibid., p. 12).

Industrial policy can be justified by further arguments (UNECA, 2016, pp.41-46). First, many industries depend on other industries, which create demand for output. Those industries thus need to be set up simultaneously so that their returns can be guaranteed. The government can promote and facilitate this process by supporting several industries at the same time. Second, investment such as research and development (R\&D) creates externalities so that there is no incentive for individual firms to invest, thus leaving the whole sector with underinvestment. Subsidies for investment may be effective. Third, quite different from standard theory, investment in the real world is fixed and long-term. Companies competing in the same emerging market might invest too many resources in such fixed structures and plants, such that total capacity is too large for market demand. The policy-maker can coordinate investment by setting up entry or investment barriers. Fourth, to enable technology transfer, the government can use instruments to ensure that foreign corporations establish R\&D facilities and take measures such as hiring local workers. Fifth, the state has the most financial means to make long-term investment, which may not be profitable immediately. Sixth, risky sectors, which are important from a development perspective, benefit from a kind of insurance if the government is willing to support them. This can also involve restructuring or nationalization when a company is in trouble.

Instead of specializing in a certain sector where a country has a comparative advantage, more active industrial policy focuses on infant industry promotion. Such policy targets certain sectors where output is supposed to grow. As long as an industry is not productive enough to compete in the world market, it is protected by tariffs and other measures such as licensing. The industry is supported until its unit costs are low 
enough to succeed in global competition without protection. Infant industry promotion was intensively used in the 19th and 20th centuries by today's advanced economies, whereas in recent decades it has been an economic policy instrument particularly in East Asia (see for instance Lee, 1997; Skarstein, 2007, pp. 359-360).

The main criticism of infant industry promotion is that protection from competition makes firms inefficient, since market pressure is absent. Even worse, protection may also outcompete more efficient sectors such that resources are allocated in the wrong firms (Sauré, 2007). To prevent such unintended outcomes, infant industry promotion has to go along with an incentive system of capacity-building, investment, worker training or $\mathrm{R} \& \mathrm{D}$, while conditioning the support on sufficient productivity growth (UNECA, 2016, p. 39).

Industrial policy became popular in development economics in Latin America right after World War II under the term "import substitution." Developing countries should be enabled to produce manufactured goods on their own, instead of importing them and therefore depending on exports of primary goods and their volatile prices. Even though active industrial policy was replaced by liberalization of trade and financial flows, it exhibited higher growth rates than the following phase (Kregel, 2008, p. 542). The reason for the abandonment was external deficits due to growing domestic incomes and hence rising demand for imports. Yet, this external constraint, to be analyzed in more detail, nonetheless requires either substitution of imports through domestic production, or export promotion in order to improve the balance of payments (Nevile \& Kriesler, 2011, p.27). This requires investment in the respective sectors.

A global overview confirms the weak position of developing countries with respect to their productive base. Annual value-added per capita in manufacturing is only a fraction of the corresponding value of advanced economies, as Figure 1.8 reveals. As a second significant difference between advanced and developing countries, the former have featured an average increase in manufacturing value-added over time, while the latter appear to be stuck at a very low level. Data seem to confirm the inability of development strategies, which are limited to trade and financial liberalization, to create a sound industrial structure. Mainly for Africa and Latin America, actual deindustrialization is observed (see for instance BresserPereira \& Theuer, 2012; Page, 2012; UNECA, 2015, pp. 46-47).

In the following analysis, industrial policy will not be investigated in all its details. Yet, there is a strong focus on the macroeconomic importance of state intervention in the form of active economic policy to develop an industrial base and foster productivity. 


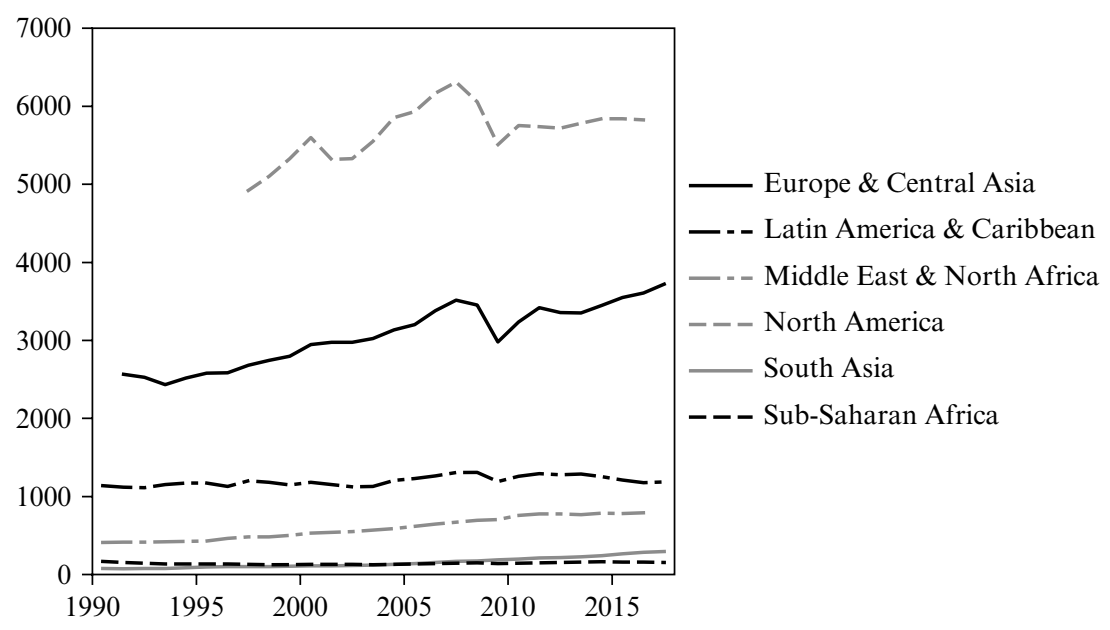

Source: World Bank (2019f), author's calculations.

Figure 1.8 Manufacturing value-added per capita 1990-2017 (constant 2010 US dollars)

\subsection{INSTITUTIONS}

Institutional economics, initiated by Thorstein Veblen, is a term which appears in Hamilton (1919) for the first time. It focuses on economic activity as being driven by institutions that in real life are imperfect, evolving in real time and influenced by human behavior. Institutional economics criticizes the neoclassical equilibrium approach while favoring the view of indeterminate economic processes. By arguing that "the human economy ... is embedded and enmeshed in institutions, economic and noneconomic," Polanyi (1957, p. 250) established the view that the market itself is an institution as well (Polanyi, 1977, p.6). The problem of economic analysis is the interaction of the technological and the social spheres creating frictions and requiring continuous institutional adjustment (Stanfield \& Wrenn, 2005, p. 27).

In contrast to institutional economics, neoclassical theory is essentially based on consumer preferences and production technology that generate an equilibrium to which the economy converges permanently and independently of institutional characteristics. However, institutions have received much more attention in mainstream economics during the past three decades. The so-called new institutional economics embeds institutional issues into the neoclassical framework. Acemoglu and Robinson 
(2012, pp. 79-83) mainly emphasize the need of "inclusive institutions"; these are institutions which guarantee private property rights and competition in the marketplace.

In development economics, the institutions approach gained importance through the international financial institutions, which increasingly made loans conditional on governance criteria (see for example Kapur $\&$ Webb, 2000). This again reinforced the institutions debate within heterodox economics, where it has a long tradition. The term "institution" is not easy to define, and is sometimes characterized by entities, sometimes by forms, and sometimes by functions (see for instance Chang, 2007, pp.18-19). Taking the first of these, institutions may be the budgetary institutions (governments), financial regulation institutions, wage- and price-setting institutions (companies and trade unions), central banks, religious institutions or the civil society. They may be expressed in forms such as democracy, independent judiciary, state ownership or the welfare state. Finally, institutions fulfill functions such as coordination of economic activities, income redistribution, technology promotion, enforceability of contracts and respect for private property.

The difficulties in finding a clear definition of institutions reveals their diverse nature. This has led to criticism of the mainstream's preference to hold the guarantee of private property rights to be the most important institutional requirement. There is no obvious argument why private property rights are always superior to public, open access and hybrid ownership patterns (Chang, 2007, pp. 22-23).

As Goldberg (2015, pp. 58-59) argues, there is largely one single kind of capitalism in Western economic thinking. It assumes that the guarantee of private property rights and contract enforceability are essential for the functioning of a capitalist economy. However, particularly in emerging countries, these two "conditions" are violated quite often. Nonetheless, the cases of China and other fast-developing countries reveal an undeniable record of many decades of economic progress. Capitalist processes often mix with public intervention on the one hand, and traditional modes of production and institutions on the other hand. In China, land is usually owned by the communities instead of held in pure private ownership, which involves different economic relationships and the persistence of a certain subsistence agriculture (ibid., pp.121-123). Kiiza (2007, pp.291-293) describes Botswana and Mauritius as two African success stories of economic development. Instead of adopting economic liberalism, developmentalism as a national ideology was institutionalized while promoting effective bureaucracy. There are certainly different forms of capitalism interwoven with various kinds of institutions.

Good institutions are often associated with characteristics such as 
democracy, an independent judiciary and a small public sector, which all countries should adopt as a "global standard institution" in order to steer development (Chang, 2007, p. 20). However, as history and differences between countries show, there is a variety of differently combined institutions that are certainly economically more successful than a global standard institution would be in the same place. In the Global South, different forms of capitalist economies exist that create different institutions, while also being influenced by them. These phenomena are described by the term "the articulation of modes of production" (see for example Goldberg, 2015, pp.77-79).

In many mainstream development discourses, the above-mentioned institutions such as the guarantee of property rights are seen as preconditions for economic development (see for example Acemoglu et al., 2005, pp.389-396). However, first, building institutions is costly. For example, in a poor country with limited resources it may be quite inefficient to develop sophisticated institutions to implement patent law, while reducing expenditures for health and education (Chang, 2011, p.488). Second, many institutions may only be established or strengthened once economic productivity of a country allows for it. Reinert (2007, p. 64) argues that, historically, only societies with a sufficient level of manufacturing have achieved the "right" institutions. "Hundreds of years of accumulated experience show that today's maxim 'get the institutions right' cannot be solved independently of 'getting into the right kind of economic activities" (ibid.). Hence, instead of the causality from institutions to economic development, the reverse causality from economic development to institution-building may be stronger (Chang, 2011, pp.476-477).

This book does not have a particular focus on institutional development. However, in the macroeconomic analysis and the subsequently developed propositions, institutions should be kept in mind. Economic policy and reforms can only be viable if they meet appropriate institutions in developing economies. Or, conversely, policy and reforms are only viable if they are appropriate for today's institutions in poor countries.

\section{NOTES}

1. For an overview and examples of non-tariff barriers such as licensing, origin and agency restrictions, see Wade (1990, pp. 128-136).

2. See Chapter 4 for a detailed analysis of the implications of balance-of-payments constrained growth. 